\title{
Origin of Open-Circuit Voltage Loss in Polymer Solar Cells and Perovskite Solar Cells
}

\section{$\operatorname{AUTHOR}(\mathrm{S})$ :}

Kim, Hyungdo; Yanagawa, Nayu; Shimazaki, Ai; Endo, Masaru; Wakamiya, Atsushi; Ohkita, Hideo; Benten, Hiroaki; Ito, Shinzaburo

\section{CITATION:}

Kim, Hyungdo ...[et al]. Origin of Open-Circuit Voltage Loss in Polymer Solar Cells and Perovskite Solar Cells. ACS Applied Materials \& Interfaces 2017, 9(23): 19988-19997

\section{ISSUE DATE:}

2017-05-29

URL:

http://hdl.handle.net/2433/226372

\section{RIGHT:}

This document is the Accepted Manuscript version of a Published Work that appeared in final form in 'ACS Applied Materials \& Interfaces', copyright $\odot$ American Chemical Society after peer review and technical editing by the publisher. To access the final edited and published work see http://doi.org/10.1021/acsami.7b03694.; The full-text file will be made open to the public on 29 May 2018 in accordance with publisher's 'Terms and Conditions for Self-Archiving'.; This is not the published version. Please cite only the published version.; この論文は出版社版でありません。引用の際には 出版社版をご確認ご利用ください。 


\title{
Origin of Open-Circuit Voltage Loss in Polymer
}

\section{Solar Cells and Perovskite Solar Cells}

\author{
Hyung Do Kim, ${ }^{1}$ Nayu Yanagawa, ${ }^{1}$ Ai Shimazaki, ${ }^{2}$ Masaru Endo, ${ }^{2}$ Atsushi Wakamiya, ${ }^{2}$ Hideo \\ Ohkita, ${ }^{*},{ }^{1}$ Hiroaki Benten, ${ }^{1}$ and Shinzaburo Ito ${ }^{1}$ \\ ${ }^{1}$ Department of Polymer Chemistry, Graduate School of Engineering, Kyoto University, \\ Katsura, Nishikyo, Kyoto 615-8510, Japan \\ ${ }^{2}$ Institute for Chemical Research, Kyoto University, Gokasho, Uji, Kyoto 611-0011, Japan.
}

Corresponding Author Footnote.

Hideo Ohkita

Tel.: +81753832614

Fax: +81753832617

Email: ohkita@photo.polym.kyoto-u.ac.jp 
Abstract

Herein, the open-circuit voltage $\left(V_{\mathrm{OC}}\right)$ loss in both polymer solar cells and perovskite solar cells is quantitatively analyzed by measuring the temperature dependence of $V_{\mathrm{OC}}$ in order to discuss the difference in the primary loss mechanism of $V_{\mathrm{OC}}$ between them. As a result, the photon energy loss for polymer solar cells is in the range of about $0.7-1.4 \mathrm{eV}$, which is ascribed to temperature-independent and -dependent loss mechanisms while that for perovskite solar cells is as small as about $0.5 \mathrm{eV}$, which is ascribed to a temperature-dependent loss mechanism. This difference is attributed to the different charge generation and recombination mechanisms between the two devices. The potential strategies for the improvement of $V_{\mathrm{OC}}$ in both solar cells are further discussed on the basis of the experimental data.

Keywords: organic-inorganic perovskites, polymer solar cells, open-circuit voltages, charge generation mechanisms, charge recombination mechanisms 


\section{Introduction}

Efficient and inexpensive photovoltaic devices are an essential prerequisite for resolving energy supply problems in the field of renewable energy. Among them, polymer solar cells and perovskite solar cells have attracted considerable attention because of the rapid advances in the device performance with potential advantages, including flexibility, high throughput productivity, and large-scale production with low-cost by using solution processes. ${ }^{1-5}$ For polymer solar cells, intensive research efforts have been devoted to developing low-bandgap polymers with high charge carrier mobility to enhance photocurrent generation. As a result, the power conversion efficiency (PCE) of polymer solar cells has been markedly improved over the past decade, and recently exceeds $10 \%$ even for single-junction cells. ${ }^{3-5}$ On the other hand, organic-inorganic metal halide perovskites such as $\mathrm{CH}_{3} \mathrm{NH}_{3} \mathrm{PbI}_{3}$ and $\mathrm{CH}_{3} \mathrm{NH}_{3} \mathrm{PbI}_{3-x} \mathrm{Cl}_{x}$ are regarded as a promising new absorber for photovoltaic devices owing to their high absorption coefficient in the visible region, Wannier-Mott exciton nature of photogenerated species, and long diffusion length of charge carriers. ${ }^{6-10}$ Recently, the PCE of perovskite solar cells has skyrocketed from 3.8 to more than $22 \%$ because of solvent engineering for preparing flat, uniform, and dense active layers with high reproducibility and optimization of the interfacial layers and device structure. ${ }^{11-14}$

Despite the substantial progress in photovoltaic performance, there is still room for further improvements in open-circuit voltage $\left(V_{\mathrm{OC}}\right)$ when taking into account the Shockley-Queisser (SQ) limit that the thermodynamically inevitable loss can be formulated for photovoltaic efficiency with a single absorber system on the basis of the optical bandgap $\left(E_{\mathrm{g}}\right)$ of the absorber. ${ }^{15}$ The photon energy loss $E_{\text {loss }}=E_{\mathrm{g}}-q V_{\mathrm{OC}}(q$ is the elementary charge) for polymer solar cells with a bulk-heterojunction structure, in which an electron donor material is mixed with an electron acceptor material, is typically in the range of about $0.7-1.1$ eV. ${ }^{16-19}$ In contrast, the $E_{\text {loss }}$ for perovskite solar cells with the architecture, based on either 
dense $\mathrm{TiO}_{2}\left(\mathrm{~d}-\mathrm{TiO}_{2}\right)$ or mesoporous $\mathrm{TiO}_{2}\left(\mathrm{mp}-\mathrm{TiO}_{2}\right)$ electron-transporting material, is reported to be $\approx 0.4-0.5 \mathrm{eV}^{20-23}$ Such values are much larger than the radiative limit $(0.25-0.30 \mathrm{eV})$ for photovoltaic cells with $E_{\mathrm{g}}$ in the range of $1.0-2.0 \mathrm{eV}$ predicted by the SQ theory. ${ }^{24}$ Therefore, an in-depth understanding of the origin of energy loss is crucially required to disclose a fundamental physics underlying device performance in both polymer solar cells and perovskite solar cells, which enables us to anticipate the upper limit of $V_{\mathrm{OC}}$ in both photovoltaic devices.

Here, we studied the origin of voltage loss in both polymer solar cells and perovskite solar cells. We fabricated polymer/fullerene and polymer/polymer blend solar cells with various polymers as shown in Figure 1. In addition, we fabricated perovskite solar cells with different electron-transporting layers of $\mathrm{d}-\mathrm{TiO}_{2}$ and $\mathrm{mp}-\mathrm{TiO}_{2}$. By measuring the temperature dependence of $V_{\mathrm{OC}}$, we discuss the difference in the loss mechanism of $V_{\mathrm{OC}}$ between polymer solar cells and perovskite solar cells quantitatively. We further discuss the potential strategies for the enhancement of $V_{\mathrm{OC}}$ in both photovoltaic devices.

\section{Results and discussion}

\subsection{Energy Diagram}

We first evaluated the $E_{\mathrm{g}}$ of the light harvesting materials to quantitate the voltage loss from photon absorption to $q V_{\mathrm{OC}}$ in both photovoltaic devices. For polymer solar cells, as shown in Figure 2a, the $E_{\mathrm{g}}$ of light harvesting materials was evaluated from the intersection point of normalized absorption and emission spectra (see Figure S1 for the other materials). For perovskite solar cells, as shown in Figure 2b, a direct bandgap was evaluated from the $x$-axis intercept of $[E \times \mathrm{EQE}]^{2}$ plotted against photon energy $E,^{25,26}$ which is consistent with the previous reports. $^{27,28}$ All the $E_{\mathrm{g}} \mathrm{s}$ are summarized in Table 1.

In the polymer solar cells, energetic cascade structures between donor and acceptor 
materials are required to provide a driving force for charge transfer (CT) at a donor/acceptor interface because photogenerated electron-hole pairs are tightly bound as an exciton in organic semiconductors. ${ }^{29-32}$ Upon photoexcitation of the donor, an electron in the lowest unoccupied molecular orbital (LUMO) of the donor can be transferred to the LUMO of the acceptor at the interface. As a result, the energy of photons absorbed drops to the energy level $\left(E_{\mathrm{DA}}\right)$, which is the energy difference between the LUMO of the acceptor and the highest occupied molecular orbital (HOMO) of the donor. Thus, it is of fundamental importance to precisely evaluate the energy offset of the LUMO levels between the donor and acceptor material $\left(\Delta q V_{\text {off }}\right)$. As shown in Figure 2 and Figure S1, we measured the HOMO of donor by the photoelectron yield spectroscopy (PYS) and LUMO of acceptor by the square wave voltammetry (SWV). The LUMO levels were calculated from the average potential of oxidation-reduction peaks on the assumption that the energy level of the ferrocene/ferrocenium redox couple is $4.8 \mathrm{eV}$ below the vacuum level. ${ }^{33}$ The resultant values are summarized in Table S1.

\subsection{Photovoltaic Performance}

In this study, we prepared a series of polymer solar cells and perovskite solar cells. The device structures of polymer solar cells are ITO/PEDOT:PSS/Polymer/Fullerene/Ca/Al and ITO/PEDOT:PSS/Polymer/Polymer/Ca/Al where ITO is an indium-tin-oxide coated glass substrate and PEDOT:PSS is a transparent conducting polymer (poly(3,4-ethylenedioxythiophene):poly(4-styrenesulfonate)). On the other hand, the device structures of perovskite solar cells are $\mathrm{FTO} / \mathrm{d}-\mathrm{TiO}_{2} / \mathrm{CH}_{3} \mathrm{NH}_{3} \mathrm{PbI}_{3} /$ spiro-OMeTAD/Au and $\mathrm{FTO} / \mathrm{d}-\mathrm{TiO}_{2} / \mathrm{mp}-\mathrm{TiO}_{2}: \mathrm{CH}_{3} \mathrm{NH}_{3} \mathrm{PbI}_{3} /$ spiro-OMeTAD/Au where FTO is an F-doped tin-oxide coated glass substrate and spiro-OMeTAD is a hole-transporting material (2,2',7,7'-tetrakis( $N, N$-di- $p$-methoxyphenylamine)-9,9-spirobifluorene). The perovskite 
active layers were prepared on $\mathrm{d}^{-\mathrm{TiO}_{2}}$ by a fast deposition-crystallization (FDC) ${ }^{14,34}$ method and on $\mathrm{mp}-\mathrm{TiO}_{2}$ by a sequential procedure. ${ }^{35,36}$

Figure 3 shows the $J-V$ characteristics of polymer solar cells and perovskite solar cells under AM1.5G simulated solar illumination with $100 \mathrm{~mW} \mathrm{~cm}{ }^{-2}$. Note that $J-V$ characteristics of perovskite solar cells were measured from 1.2 to $-0.50 \mathrm{~V}$ (reverse scan) with a delay time of $1 \mathrm{~s}$. The photovoltaic parameters of these cells are summarized in Table S2. Although the polymer solar cells exhibit a slight decrease in the short-circuit current density $\left(J_{\mathrm{SC}}\right)$ and fill factor $(\mathrm{FF})$ compared to those reported previously because each device was not fully optimized, $V_{\mathrm{OC}}$ is in good agreement with previous reports. ${ }^{37-42}$ On the other hand, the perovskite solar cells exhibit a moderate device performance with a small $J-V$ hysteresis, which has an influence mainly on FF but has negligible effect on $J_{\mathrm{SC}}$ and $V_{\mathrm{OC}}$ as shown in Figure S2. Therefore, we can safely discuss the origin of loss mechanisms in $V_{\mathrm{OC}}$ without regard to hysteresis effects as a function of sweep directions. Most importantly, as summarized in Table $1, E_{\text {loss }}$ for polymer solar cells is $0.2-0.9 \mathrm{eV}$ larger than that for perovskite solar cells, implying a big difference between them with respect to loss mechanisms in $V_{\mathrm{OC}}$. This will be discussed in more detail in the subsequent section.

\subsection{Origin of Energy Loss from $E_{\mathrm{g}}$ to $E_{\mathrm{g}}{ }^{\text {eff }}$}

To address the origin of $V_{\mathrm{OC}}$ loss in both polymer solar cells and perovskite solar cells, we measured the temperature dependence of $V_{\mathrm{OC}}$ as shown in Figure 4 and Figure S3. Under the open-circuit condition, the difference between quasi-Fermi levels of electrons and holes is constant across the device. Hence, the temperature dependence of $V_{\mathrm{OC}}$ is given by ${ }^{43,44}$

$$
q V_{\mathrm{OC}}=E_{\mathrm{g}}^{\mathrm{eff}}-k_{\mathrm{B}} T \ln \left(\frac{N_{0}^{2}}{n_{\mathrm{e}} n_{\mathrm{h}}}\right)
$$

where $E_{\mathrm{g}}{ }^{\text {eff }}$ is the effective bandgap energy of the semiconductors, $k_{\mathrm{B}}$ is the Boltzmann 
constant, $T$ is the absolute temperature, $n_{\mathrm{e}}$ and $n_{\mathrm{h}}$ are the density of electrons and that of holes, respectively, and $N_{0}$ is the density of electronic states in the device. On the basis of Equation (1), we can evaluate the $E_{\mathrm{g}}{ }^{\text {eff }}$ from a linear extrapolation at $0 \mathrm{~K}$ when the photocurrent density generated is almost independent of temperature. The values of $E_{\mathrm{g}}{ }^{\text {eff }}$ for both photovoltaic devices are summarized in Table 1.

We first focus on the energy loss from $E_{\mathrm{g}}$ to $E_{\mathrm{g}}$ eff observed for polymer solar cells and perovskite solar cells. For polymer solar cells, as mentioned before, there is an energy loss to generate free charge carriers from excitons, which is called the energy offset $\Delta q V_{\text {off }}$ estimated from the energy difference between $E_{\mathrm{g}}$ and $E_{\mathrm{DA}}$. As summarized in Table 1, the $\Delta q V_{\text {off }}$ is as large as $0.9 \mathrm{eV}$ for $\mathrm{P} 3 \mathrm{HT} / \mathrm{PCBM}$ and as small as about $0.2 \mathrm{eV}$ for P3HT/PF12TBT. This offset $\Delta q V_{\text {off }}$ is one of the primary voltage losses in polymer solar cells. In addition, the $E_{\mathrm{g}}{ }^{\text {eff }}$ is about $0.2-0.3 \mathrm{eV}$ smaller than the $E_{\mathrm{DA}}$, which is estimated from the HOMO and LUMO energy levels for individual donor and acceptor materials that have no electronic interaction between them. The CT state formed in donor/acceptor blends should have Coulomb binding energy $\Delta E_{\mathrm{C}}$ in polymer solar cells, which is given by ${ }^{29}$

$$
\Delta E_{\mathrm{C}}=\frac{q^{2}}{4 \pi \varepsilon_{0} \varepsilon_{\mathrm{r}} R}
$$

Here, $\varepsilon_{\mathrm{r}}$ is the relative dielectric constant of the surrounding media, $\varepsilon_{0}$ is the permittivity of vacuum, $R$ is the electron-hole separation distance, and $\Delta E_{\mathrm{C}}$ is the energy of Coulomb attraction. The dielectric constant $\varepsilon_{\mathrm{r}}$ has been reported to be $\approx 3$ for most of conjugated polymer films and to be 3.9 for PCBM films. ${ }^{29,45-47}$ In this calculation, $\varepsilon_{\mathrm{r}}=3.5$ was used as an average value for all the polymer solar cells studied and $R$ was employed as a fitting parameter. On the basis of Equation (2) with $\varepsilon_{\mathrm{r}}=3.5$ and $R=1.2-1.6 \mathrm{~nm}$, the $\Delta E_{\mathrm{C}}$ is roughly estimated to be $\approx 0.3 \mathrm{eV}$, which is consistent with the difference between $E_{\mathrm{g}}$ eff and $E_{\mathrm{DA}}$. Such a small $R$ is consistent with the electron-hole separation distance in the CT state formed at the 
donor/acceptor interface. ${ }^{29,46,48}$ We therefore ascribe the energy difference between $E_{\mathrm{DA}}$ and $E_{\mathrm{g}}{ }^{\text {eff }}$ to the Coulomb binding energy $\Delta E_{\mathrm{C}}$ of the CT state formed at the donor/acceptor interface in polymer solar cells. On the other hand, the $E_{\mathrm{g}}$ eff evaluated for perovskite solar cells is almost equal to the $E_{\mathrm{g}}$ of perovskites. This indicates that the free charge carrier can be directly formed after photon absorption because of the small exciton binding energy. ${ }^{49,50}$ Furthermore, this finding indicates that the primary charge recombination in perovskite solar cells is the bulk recombination in perovskite absorber rather than the surface recombination at the interface. ${ }^{51-53}$ In summary, polymer solar cells have two loss channels of the energy offset $\Delta q V_{\text {off }}$ and the Coulomb binding energy $\Delta E_{\mathrm{C}}$ while perovskite solar cells have no loss channel in the energy loss from $E_{\mathrm{g}}$ to $E_{\mathrm{g}}$ eff. This difference originates from the difference in the charge generation mechanisms between polymer solar cells and perovskite solar cells.

\subsection{Origin of Energy Loss from $E_{\mathrm{g}}$ to $E_{\mathrm{g}}{ }^{\text {eff }}$}

We next focus on the temperature-dependent energy loss from $E_{\mathrm{g}}{ }^{\text {eff }}$ to $q V_{\mathrm{OC}}\left(\Delta q V_{\text {temp }}\right)$ observed for polymer solar cells and perovskite solar cells as shown in Figure 4. As discussed in the previous section, we evaluated the $E_{\mathrm{g}}{ }^{\text {eff }}$ from a linear extrapolation at $0 \mathrm{~K}$ to clarify the primary charge recombination sites in the two devices. As a result, we found that charge recombination is dominant in the $\mathrm{CT}$ state formed at the interface of donor and acceptor materials for polymer solar cells and in the bulk of perovskites for perovskite solar cells.

The charge recombination mechanisms can be discussed on the basis of the temperature-dependent voltage loss $\Delta q V_{\text {temp }}$ as reported previously. ${ }^{25,53-58}$ Under the open-circuit condition, the charge generation rate is equal to the total recombination rate because of no charge collection to external electrodes. Recently, the voltage loss in organic solar cells has been discussed in the frame work of a modified SQ theory taking into account 
the essential effects of the CT state formed at the donor/acceptor interface. ${ }^{24,59-61}$ In this approach, both the sun and photovoltaic device are considered as black body radiations at $5778 \mathrm{~K}$ for the surface of the sun and at $300 \mathrm{~K}$ for the photovoltaic device, respectively. According to Planck's law of radiation, the number of photons per unit area and time $N(T)$, absorbed or emitted by the black body at a certain temperature, can be given by the integral of the black body spectrum over all photon energies $E$.

$$
\begin{aligned}
N(T) & =\int_{0}^{\infty} \eta_{\mathrm{A}}(E) n(E, T) \mathrm{d} E \\
& =\int_{0}^{\infty} \eta_{\mathrm{A}}(E) \frac{1}{4 \pi^{2} \hbar^{3} c^{2}}\left[\exp \left(\frac{E}{k_{\mathrm{B}} T}\right)-1\right]^{-1} E^{2} \mathrm{~d} E
\end{aligned}
$$

where $\eta_{\mathrm{A}}(E)$ is the absorption spectrum, $n(E, T)$ is the flux of photons with an energy of $E, \hbar$ is reduced Planck's constant, and $c$ is the speed of light in vacuum. In the modified SQ theory, $\eta_{\mathrm{A}}(E)$ consists of not only the absorption of bulk materials for photon energies above the $E_{\mathrm{g}}$ $\left(\eta_{\mathrm{A}}{ }^{\text {Bulk }} \approx 1\right)$, but also the absorption of the CT state in donor/acceptor blend for $E_{\mathrm{CT}}<E<E_{\mathrm{g}}$ (typically, $\eta_{\mathrm{A}}{ }^{\mathrm{CT}} \approx 10^{-6}-10^{-4}$ ). ${ }^{24,62-65}$ Hence, the absorption profile can be given by two step functions:

$$
\eta_{\mathrm{A}}(E)= \begin{cases}0 & \text { for } E<E_{\mathrm{CT}} \text { or } E_{\mathrm{g}} \\ \eta_{\mathrm{A}}^{\mathrm{CT}} & \text { for } \quad E_{\mathrm{CT}}<E<E_{\mathrm{g}} \\ \eta_{\mathrm{A}}^{\text {Bulk }} & \text { for } \quad E>E_{\mathrm{g}}\end{cases}
$$

Assuming one electron-hole pair is generated by each photon absorbed by the photovoltaic devices, $J_{\mathrm{SC}}$ is given by $J_{\mathrm{SC}}=q s N(T)$ where $s\left(\approx 2.18 \times 10^{-5}\right)$ is a fraction of the photons reaching the surface of the earth and $T \approx 5778 \mathrm{~K}^{24}$ On the other hand, the generated photons, driven by a radiative recombination of electrons and holes at $T \approx 300 \mathrm{~K}$ and $s=1$ in the photovoltaic devices, can be expressed by $J_{0, \text { rad }}=q N(T){ }^{24}$ Under the open circuit condition, the equilibrium condition under which the number of photons absorbed is equal to that of photons emitted is established. Taking into account the ideal diode that the current is only 
driven by the radiative recombination, which is given by $J_{0}\left[\exp \left(q V / k_{\mathrm{B}} T\right)-1\right]^{43,44}$ for a negligibly small series resistor $\left(R_{\mathrm{s}} \approx 0\right)$, and an ideal parallel resistor $\left(R_{\mathrm{p}} \rightarrow \infty\right), V_{\mathrm{OC}}$ can be derived by

$$
q V_{\mathrm{OC}}=k_{\mathrm{B}} T \ln \left(\frac{J_{\mathrm{SC}}}{J_{0}}+1\right)
$$

where $J_{0}$ is the saturation current density at reverse bias. Note that $J_{0}$ is typically due to not only the current driven by the radiative recombination but also the current via the non-radiative recombination in the real photovoltaic devices, and hence is given by $J_{0}=J_{0 \text {,rad }}$ $+J_{0, \text { non }}$. By substituting this relationship into Equation (5), Equation (6) can be obtained.

$$
q V_{\mathrm{OC}}=k_{\mathrm{B}} T \ln \left(\frac{J_{\mathrm{SC}}}{J_{0, \text { rad }}+J_{0, \text { non }}}+1\right)
$$

Using $J_{0}$ given by the Arrhenius equation (Supporting Information), ${ }^{43,44}$ the temperature dependence of $V_{\mathrm{OC}}$ is rewritten as

$$
q V_{\mathrm{OC}}(T)=E_{\mathrm{g}}^{\mathrm{eff}}-\Delta q V_{\mathrm{rad}}(T)-\Delta q V_{\text {non }}(T)
$$

where $\Delta q V_{\text {rad }}$ and $\Delta q V_{\text {non }}$ are the radiative and non-radiative loss in $V_{\mathrm{OC}}$, respectively.

The $\eta_{\mathrm{A}}{ }^{\mathrm{CT}}$ for polymer blend solar cells has been typically reported to be in the range of $10^{-6}$ to $10^{-4} \cdot{ }^{24,62-65}$ In this analysis, $J_{0, \text { rad }}$ was calculated by Equation (3) with $\eta_{\mathrm{A}}{ }^{\text {Bulk }}=1$ for polymer solar cells and perovskite solar cells and $\eta_{\mathrm{A}}{ }^{\mathrm{CT}}=1.0 \times 10^{-4}$ for all the polymer solar cells or $\eta_{\mathrm{A}}{ }^{\mathrm{CT}}=0$ for perovskite solar cells. We note that the smaller $\eta_{\mathrm{A}}{ }^{\mathrm{CT}}\left(=1.0 \times 10^{-6}\right)$ simply results in the smaller radiative loss in $V_{\mathrm{OC}}$ for polymer solar cells and hence does not affect our discussion on the difference in $\Delta q V_{\text {temp }}$ between polymer solar cells and perovskite solar cells at all. For $J_{\mathrm{SC}}$, each experimental value was employed. Here, we replace $E_{\mathrm{CT}}$ with $E_{\mathrm{g}}{ }^{\text {eff }}\left(E_{\mathrm{CT}}=E_{\mathrm{g}}{ }^{\text {eff }}\right)$ because $q V_{\mathrm{OC}}$ converges $E_{\mathrm{g}}{ }^{\text {eff }}$ in accordance with Equation (1). As shown in Figure 4 and Table 1, the $\Delta q V_{\text {temp }}$ at room temperature is evaluated to be $\approx 0.3-0.4$ $\mathrm{eV}$ for polymer solar cells, while it is as large as about $0.5 \mathrm{eV}$ for perovskite solar cells. 
These findings suggest that there should be a different loss process in $V_{\mathrm{OC}}$ between them. As shown in Figure 5 and Figure S4, the temperature dependence of $V_{\mathrm{OC}}$ was well fitted with Equation (6) taking into account $J_{0}$ that both the radiative and non-radiative recombinations contribute to the device dark current. All the fitting parameters are summarized in Table S3. The dashed-two-dotted lines in Figure 5 show the radiative recombination loss $\Delta q V_{\text {rad }}$ in the photovoltaic devices plotted against temperature. This voltage loss in $V_{\mathrm{OC}}$ is thermodynamically inevitable, because it is strongly dependent on the absorption coefficient of bulk materials and the CT state in donor/acceptor blend films. ${ }^{24,59-61}$ As shown in Figure $5, \Delta q V_{\text {rad }}$ is evaluated to be $\approx 0.1 \mathrm{eV}$ for polymer solar cells while it is evaluated to be $\approx 0.3 \mathrm{eV}$ for perovskite solar cells. This is ascribed to small $\eta_{\mathrm{A}}{ }^{\mathrm{CT}}$ of the organic donor/acceptor blend, which is typically in the range of $10^{-6}-10^{-4} \cdot 24,62-65$ On the other hand, $\Delta q V_{\text {non }}$ was evaluated to $\mathrm{be} \approx 0.2-0.3 \mathrm{eV}$ for polymer solar cells and $\approx 0.2 \mathrm{eV}$ for perovskite solar cells. In summary, $\Delta q V_{\text {non }}$ is the major loss channel for polymer solar cells while $\Delta q V_{\text {rad }}$ is the major loss channel for perovskite solar cells. This discrepancy is ascribed to the difference in the charge recombination mechanisms between them.

\subsection{Potential Strategies for Enhancement in $V_{\mathrm{OC}}$}

We further discuss the potential strategies for the enhancement of $V_{\mathrm{OC}}$ in both polymer solar cells and perovskite solar cells. As summarized in Figure 6, the $E_{\text {loss }}$ can be divided into the

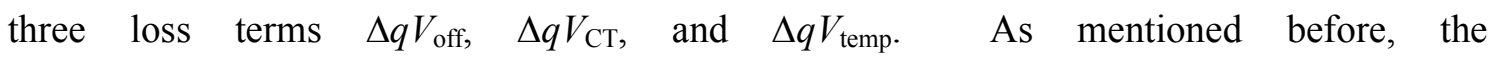
temperature-independent $\Delta q V_{\text {off }}$ and $\Delta q V_{\mathrm{CT}}$ are the major loss channels for polymer solar cells while they are not found at all for perovskite solar cells. For polymer solar cells, the minimal offset energy for the sum of $\Delta q V_{\text {off }}$ and $\Delta q V_{\mathrm{CT}}$ has been considered to be $\geq 0.3 \mathrm{eV}$ to ensure an efficient charge transfer at the D/A interface, previously. ${ }^{30-32}$ However, recent studies have shown that efficient charge transfer could be possible even for a negligibly small 
offset energy $\left(\Delta q V_{\text {off }}+\Delta q V_{\mathrm{CT}} \leq 0.1 \mathrm{eV}\right) .{ }^{17,19,63}$ Although little is known about the underlying mechanism for such efficient charge transfer with a small offset energy, the $\Delta q V_{\text {off }}$ $+\Delta q V_{\mathrm{CT}}$ may be reduced to less than $0.1 \mathrm{eV}$ even for polymer solar cells.

We next discuss the temperature-dependent voltage loss $\Delta q V_{\text {temp }}$ in polymer solar cells. As described before, we found that the dominant charge recombination sites are the CT state at the donor/acceptor interface in polymer solar cells. On the basis of the modified SQ model, the $\Delta q V_{\text {rad }}$ is estimated to be $\approx 0.1 \mathrm{eV}$ due to the weak absorption coefficient of the CT state, and hence the $\Delta q V_{\text {non }}$ is a major loss channel in the $\Delta q V_{\text {temp. }}$ As discussed in previous studies, the $\Delta q V_{\text {non }}$ is mainly ascribed to the interfacial disorder. ${ }^{66-68}$ The optical absorption near band edges in the disorder of materials exhibits an Urbach tail, which is given by $\alpha(E)=$ $\alpha_{0} \exp \left(\left(E-E_{\mathrm{g}}\right) / E_{\mathrm{u}}\right)$ for $E<E_{\mathrm{g}}$ where $\alpha(E)$ is the absorption coefficient, $\alpha_{0}$ is a constant determined by fits to the experiment, and $E_{\mathrm{u}}$ is the Urbach energy. The disorder of materials therefore can correlate with the $E_{\mathrm{u}}$. It is well known that the $E_{\mathrm{u}}$ of organic materials is in the range of 30-60 meV, being 2 to 4 times higher than that of perovskites. ${ }^{17,69-71}$ This indicates that energetic disorder is larger in organic donor/acceptor films than in perovskite materials. Hence, the reduction of the disorder at the CT state is of key importance to suppress the $\Delta q V_{\text {temp }}$ in polymer solar cells. A recent study has shown that conjugated polymers with a low degree of energetic disorder can be prepared by the introduction of torsion-free backbone conformation with a remarkable resilience. ${ }^{71}$ Such a molecular design could reduce the disorder at the CT state and hence suppress the $\Delta q V_{\text {temp }}$ in polymer solar cells. Although further studies are necessary to give a guideline in terms of the suitable molecular design for donor/acceptor blend with a low degree of disorder as well as a small offset energy, we suggest that the $V_{\mathrm{OC}}$ in polymer solar cells can be increased by minimizing the offset energy $\left(\Delta q V_{\text {off }}+\Delta q V_{\mathrm{CT}} \leq 0.1 \mathrm{eV}\right)$ as well as by suppressing the disorder of donor/acceptor interface $\left(\Delta q V_{\text {temp }} \leq 0.3 \mathrm{eV}\right)$ while keeping efficient charge generation, and hence achieve the upper 
limit of $V_{\mathrm{OC}}\left(E_{\text {loss }} \leq 0.4 \mathrm{eV}\right)$ as shown in Figure $6 \mathrm{a}$.

Finally, we discuss the temperature-dependent voltage loss $\Delta q V_{\text {temp }}$ in perovskite solar cells. As mentioned before, the major loss channel in $\Delta q V_{\text {temp }}$ is the inevitable $\Delta q V_{\text {rad }}$ because of the strong absorption coefficient of perovskites $\left(10^{4}-10^{5} \mathrm{~cm}^{-1}\right.$ at $\left.550 \mathrm{~nm}\right)$. As such, it is very important to suppress the $\Delta q V_{\text {non }}$ in perovskite solar cells for further improvement. As reported previously, ${ }^{25,34,72}$ the $\Delta q V_{\text {non }}$ is dependent upon the trap densities $N_{\mathrm{t}}$ in perovskite solar cells. If the trap density were as small as $<10^{13} \mathrm{~cm}^{-3}, \Delta q V_{\text {non }}$ would be negligibly small and hence $V_{\mathrm{OC}}$ could be improved to up to $\approx 1.3 \mathrm{~V} .^{34,72}$ This is in good agreement with the value expected from the modified SQ model without taking into account $\Delta q V_{\text {non }}$ as shown in Figure 6b. In this context, the fabrication of pure perovskites with low trap state densities is a key issue to further enhance the $V_{\mathrm{OC}}$ in perovskite solar cells. Recently, an extremely low $N_{\mathrm{t}}$ of $<10^{13} \mathrm{~cm}^{-3}$ has been reported for highly crystalline perovskites with mm-scale grains. ${ }^{73}$ However, the $V_{\mathrm{OC}}$ is still far from the SQ limit. ${ }^{74,75}$ This indicates that there should be other loss mechanisms such as the energy level alignment or surface recombination at the interface. We therefore conclude that the $V_{\mathrm{OC}}$ in perovskite solar cells can be further improved not only by suppressing additional recombination channels ( $\Delta q V_{\text {temp }} \approx 0.3 \mathrm{eV}$ ) but also by employing high quality perovskites with the low trap density, and thus attain the SQ limit of $V_{\mathrm{OC}}\left(E_{\mathrm{loss}} \approx 0.3 \mathrm{eV}\right)$ as shown in Figure $6 \mathrm{~b}$. Note that very recent studies have shown that the photon recycling of the perovskite layers in the device structure, which can confine the incoming photon, causes the higher internal photon densities. $^{76-78}$ Such effects would enhance the achievable $V_{\mathrm{OC}}$ furthermore.

\section{Conclusions}

We systematically studied the origin of the $V_{\mathrm{OC}}$ loss in a series of polymer solar cells and perovskite solar cells. The polymer solar cells were fabricated by spin-coating from the 
blend solutions with a different composition of either polymer/fullerene blend or polymer/polymer blend in which the conjugated polymers with different $E_{\mathrm{g}} \mathrm{s}$ were employed. On the other hand, the perovskite solar cells were prepared on $\mathrm{d}-\mathrm{TiO}_{2}$ by the FDC method and on $\mathrm{mp}-\mathrm{TiO}_{2}$ by the sequential procedure.

By measuring the temperature dependence of $V_{\mathrm{OC}}$, we quantified the voltage loss in both devices and clarified the difference in the dominant loss process between them. As a result, we found that the photon energy loss for polymer solar cells is in the range of about $0.7-1.4$

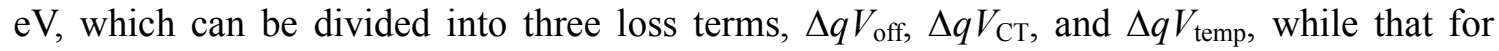
perovskite solar cells is as small as about $0.5 \mathrm{eV}$ through a temperature-dependent loss process $\left(\Delta q V_{\text {temp }}\right)$. In particular, the temperature-independent $\Delta q V_{\text {off }}$ and $\Delta q V_{\mathrm{CT}}$, which are not found at all for perovskite solar cells, are the dominant loss channels for polymer solar cells. The large $E_{\mathrm{b}}$ of organic semiconductors is believed to necessitate the energetic cascade between donor and acceptor materials to guarantee an efficient charge separation in polymer solar cells. This is accompanied with $\Delta q V_{\text {off, }}$ which was estimated from the difference of LUMO energy levels between individual donor and acceptor material. These values are in the range of $0.2-0.9 \mathrm{eV}$ depending on the donor/acceptor blend. In addition, there is an additional energy loss from $E_{\mathrm{DA}}$ to $E_{\mathrm{g}}{ }^{\text {eff }}\left(\Delta q V_{\mathrm{CT}}\right)$, which amounts to $\approx 0.2-0.3 \mathrm{eV}$. We ascribe this loss term to the Coulomb binding energy $\Delta E_{\mathrm{C}}$ of the CT state formed at the donor/acceptor interface. Therefore, the difference in charge generation mechanisms between polymer solar cells and perovskite solar cells results in the different energy loss mechanism from $E_{\mathrm{g}}$ to $E_{\mathrm{g}}$ eff .

The temperature-dependent energy $\operatorname{loss}\left(\Delta q V_{\text {temp }}\right)$ in both polymer solar cells and perovskite solar cells is closely related to charge recombination mechanisms. For polymer solar cells $\Delta q V_{\text {temp }}$ was as small as about $0.3-0.4 \mathrm{eV}$ whereas for perovskite solar cells it was estimated to be $\approx 0.5 \mathrm{eV}$. We have quantitatively analyzed $\Delta q V_{\text {temp }}$ in both devices based on 
the modified SQ theory including the effect of the interfacial CT state, which can be divided into radiative recombination and non-radiative recombination. As a result, $\Delta q V_{\text {rad }}$ was as small as about $0.1 \mathrm{eV}$ for polymer solar cells while it was evaluated to be $\approx 0.3 \mathrm{eV}$ for perovskite solar cells, which is comparable to the thermodynamically inevitable loss for photovoltaic efficiency with a single absorber system. Such a small $\Delta q V_{\text {rad }}$ for polymer solar cells is attributed to a small $\eta_{\mathrm{A}}{ }^{\mathrm{CT}}$ of the organic donor/acceptor blend, which is typically in the range of $10^{-6}-10^{-4}$. On the other hand, $\Delta q V_{\text {non }}$ was evaluated to be $\approx 0.2-0.3 \mathrm{eV}$ for polymer solar cells and $\approx 0.2 \mathrm{eV}$ for perovskite solar cells. In summary, the primary loss channel is $\Delta q V_{\text {non }}$ for polymer solar cells and $\Delta q V_{\text {rad }}$ for perovskite solar cells, which consequently have a primary impact on $\Delta q V_{\text {temp. }}$ This difference results from the difference in mechanism of charge recombination between them.

Our study shows that there is still substantial potential for improving the $V_{\mathrm{OC}}$ in polymer solar cells and perovskite solar cells because an additional loss has a significant portion of $E_{\text {loss }}$ as compared to the SQ limit value $\left(\Delta q V_{\mathrm{rad}}\right)$. Hence, we estimated the upper limit of $V_{\mathrm{OC}}$ in both devices on the basis of these experimental data. In polymer solar cells, $E_{\text {loss }} \leq 0.4 \mathrm{eV}$ would be achievable by the introduction of donor/acceptor blend with the minimal offset energy $\left(\Delta q V_{\text {off }}+\Delta q V_{\mathrm{CT}} \leq 0.1 \mathrm{eV}\right)$ as well as a low degree of disorder at the interfacial $\mathrm{CT}$ state. On the other hand, in perovskite solar cells, the thermodynamically unavoidable loss $\left(E_{\text {loss }} \approx 0.3 \mathrm{eV}\right)$ would be attainable not only by suppressing the additional recombination channels but also by preparing high quality perovskites with low trap density, resulting in high device performance comparable to crystalline silicon solar cells. Photon recycling reported recently would enhance the attainable $V_{\mathrm{OC}}$ furthermore. As such, our quantitative analysis offers a clear target for further enhancement of $V_{\mathrm{OC}}$ in polymer solar cells and perovskite solar cells, and thus high PCE. 


\section{Experimental Section}

Materials: All of the polymers were employed without further purification as follows: P3HT (Sigma-Aldrich, regioregularity $>90 \%, M_{\mathrm{w}}=42,300 \mathrm{~g} \mathrm{~mol}^{-1}$, and PDI $=1.9$ ), PTQ1 (Solarmer Materials, Inc., $M_{\mathrm{w}}=113,000 \mathrm{~g} \mathrm{~mol}^{-1}$, and PDI $\left.=2.4\right)$, PCDTBT (Ossila, $M_{\mathrm{w}}=$ 42,200 $\mathrm{g} \mathrm{mol}^{-1}$, and PDI $\left.=2.15\right)$, PBDTTT-EF-T (1-Materials Inc., $M_{\mathrm{w}}=121,000 \mathrm{~g} \mathrm{~mol}^{-1}$, and PDI $=2.4$ ), N2200 (Polyera Corporation, $M_{\mathrm{w}}=84,300 \mathrm{~g} \mathrm{~mol}^{-1}$, and PDI $=3.1$ ), and PCBM (Frontier Carbon, 99.9\%). PF12TBT $\left(M_{\mathrm{w}}=78000 \mathrm{~g} \mathrm{~mol}^{-1}\right.$ and PDI $\left.=2.8\right)$ was synthesized at Sumitomo Chemical Co., Ltd.

$\mathrm{CH}_{3} \mathrm{NH}_{3} \mathrm{I}$ (MAI) was synthesized according to the procedures reported previously. ${ }^{34} \mathrm{~A}$ methanol solution of methylamine $(90 \mathrm{~mL}, 40 \%, 0.882 \mathrm{M}$; Wako Pure Chemical Industries, Ltd.) was added drop wise over $10 \mathrm{~min}$ to an aqueous solution of $\mathrm{HI}(96.9 \mathrm{~mL}, 57 \mathrm{wt} \%, 1.29$ M; Wako Pure Chemical Industries Ltd.) in a $500 \mathrm{~mL}$ round bottom flask at $0{ }^{\circ} \mathrm{C}$, and then stirred for $2 \mathrm{~h}$. The precipitates were recovered by evaporation at $50{ }^{\circ} \mathrm{C}$ for $30 \mathrm{~min}$. The resultant yellowish raw products were dissolved in ethanol, recrystallized from diethyl ether, and then finally filtered. These steps were repeated three times. After filtration, the white solid products MAI were dried at $60^{\circ} \mathrm{C}$ in a vacuum oven for $24 \mathrm{~h}$.

Device Fabrication: Polymer solar cells were fabricated as follows. A hole-transporting buffer layer $(40 \mathrm{~nm})$ of poly(3,4-ethylenedioxythiophene) with poly(4-styrenesulfonate) (PEDOT:PSS, H. C. Starck Clevios PH500) was prepared atop a UV-ozone-cleaned ITO-coated glass substrate (a sheet resistance of $10 \Omega$ per square) by spin-coating at $3000 \mathrm{rpm}$ for $99 \mathrm{~s}$ and then heated on a hot plate at $140{ }^{\circ} \mathrm{C}$ for $10 \mathrm{~min}$. The photoactive layers used in this study were prepared on the ITO/PEDOT:PSS substrate by spin-coating from a blend solution with a different weight ratio based on polymer/fullerene derivative and polymer/polymer blends in a nitrogen atmosphere. The six blend solutions were prepared by 
dissolving P3HT (7.5 mg) and PCBM (6 mg) in $1 \mathrm{~mL}$ of chlorobenzene (CB), PTQ1 (19.5 $\mathrm{mg})$ and PCBM $(26.5 \mathrm{mg})$ in $1 \mathrm{~mL}$ of $o$-dichlorobenzene $(o-\mathrm{DCB})$, PCDTBT $(10 \mathrm{mg})$ and PCBM (40 mg) in $1 \mathrm{~mL}$ of CB, P3HT (5.5 mg) and PF12TBT $(5.5 \mathrm{mg})$ in $1 \mathrm{~mL}$ of chloroform (CF), PTQ1 (8.4 mg) and N2200 (3.6 mg) in $1 \mathrm{~mL}$ of CF, and PBDTTT-EF-T (9 mg) and $\mathrm{N} 2200(9 \mathrm{mg})$ in $1 \mathrm{~mL}$ of $\mathrm{CB}$, respectively. P3HT/(PCBM or PF12TBT), PCDTBT/PCBM and PTQ1/N2200 blend films were annealed on a hot plate at $140{ }^{\circ} \mathrm{C}$ for $10 \mathrm{~min}$ and $80{ }^{\circ} \mathrm{C}$ for $15 \mathrm{~min}$ and $120^{\circ} \mathrm{C}$ for $10 \mathrm{~min}$ under the nitrogen atmosphere, respectively. The thickness of blend layers varied from 60 to $140 \mathrm{~nm}$ according to a given donor/acceptor blend system. After being heated, the samples were transferred to a glovebox under an inert nitrogen atmosphere. A calcium interlayer $(\mathrm{Ca}, 12 \mathrm{~nm})$ and an aluminium electrode $(\mathrm{Al}, 70 \mathrm{~nm})$ were thermally deposited on top of the active layer under high vacuum $\left(<2.5 \times 10^{-4} \mathrm{~Pa}\right)$. At least 6 devices were fabricated to ensure the reproducibility of the $J-V$ characteristics.

Two types of perovskite solar cells were fabricated with either d- $\mathrm{TiO}_{2}$ or $\mathrm{mp}-\mathrm{TiO}_{2}$ based device structure in which the active layers were obtained by a fast deposition-crystallization $(\mathrm{FDC})^{14,34}$ method and a sequential procedure, respectively. ${ }^{35,36}$ A dense layer of $\mathrm{TiO}_{2}(\approx 40$ nm) was coated atop a UV-ozone cleaned FTO-coated glass substrate (a sheet resistance of $12 \Omega$ per square, $25 \mathrm{~mm} \times 25 \mathrm{~mm}$, Asahi Glass Co., Ltd.) by spray-pyrolysis at $470{ }^{\circ} \mathrm{C}$ using a bis(isopropoxide)bis(acetylacetonato)titanium(IV) solution $(75 \mathrm{wt} \%$ in 2-propanol, Sigma-Aldrich) diluted in ethanol (1:39, volume ratio).

To prepare d- $\mathrm{TiO}_{2}$ based $\mathrm{PHJ}$ devices, the $\mathrm{MAPbI}_{3}$ perovskite solutions $(55 \mathrm{wt} \%, 1160 \mathrm{mg}$ $\mathrm{mL}^{-1}$ ) were prepared by mixing MAI with purified $\mathrm{PbI}_{2}$ (L0279 for perovskite precursor, Tokyo Chemical Industry Co., Ltd. $)^{36}$ at a molar ratio of 1 to 1 in anhydrous $\mathrm{N}, \mathrm{N}$-dimethylformamide (DMF, 99.8\%, Sigma-Aldrich) and then stirred at $70{ }^{\circ} \mathrm{C}$ overnight in a nitrogen-filled glove box $\left(\mathrm{H}_{2} \mathrm{O}\right.$ and $\left.\mathrm{O}_{2}<1 \mathrm{ppm}\right)$. In the glove box, the $\mathrm{MAPbI}_{3}$ solution $(0.13 \mathrm{~mL})$ was first dropped onto the center of a d-TiO ${ }_{2}$ coated FTO substrate. The substrate 
was firstly spun at $5000 \mathrm{rpm}$ for $30 \mathrm{~s}$, and after $6 \mathrm{~s}$ anhydrous $\mathrm{CB}(99.8 \%, 0.3 \mathrm{~mL}$, Sigma-Aldrich) was quickly dropped onto the center of the substrate. The instant color change of films from yellow to brown was observed upon dropping CB solvent. The resulting dark brown films were dried at $100{ }^{\circ} \mathrm{C}$ for $10 \mathrm{~min}$. The hole-transporting layer was deposited on the perovskite layer by spin-coating at $4000 \mathrm{rpm}$ for $30 \mathrm{~s}$ from a solution of spiro-OMeTAD (72.3 mg, Merck) in anhydrous CB (99.8\%, $1.0 \mathrm{~mL}$, Sigma-Aldrich) containing $28.8 \mu \mathrm{L}$ of 4-tert-butylpyridine (Sigma-Aldrich) and $17.5 \mu \mathrm{L}$ of lithium bis(trifluoromethanesulfonyl)imide (Li-TFSI) solution (520 mg Li-TFSI in $1 \mathrm{~mL}$ acetonitrile, Sigma-Aldrich).

To prepare $\mathrm{mp}-\mathrm{TiO}_{2}$ based perovskite solar cells, the $\mathrm{d}-\mathrm{TiO}_{2}$ layer was treated with a solution of $\mathrm{TiCl}_{4}(440 \mu \mathrm{L}$, special grade, Wako Pure Chemical Industries Ltd.) in $100 \mathrm{~mL}$ of water at $70{ }^{\circ} \mathrm{C}$ for $30 \mathrm{~min}$, and rinsed twice with distilled water. The substrates were sintered at $500{ }^{\circ} \mathrm{C}$ for $20 \mathrm{~min}$, and subsequent spin-coating at $5000 \mathrm{rpm}$ for $30 \mathrm{~s}$ from a diluted solution of $\mathrm{TiO}_{2}$ paste (PST-18NR, JGC Catalysts and Chemicals Ltd.) with the weight ratio of $\mathrm{TiO}_{2}$ paste : ethanol $=1: 3.5$, followed by sintering at $500{ }^{\circ} \mathrm{C}$ for $30 \mathrm{~min}$, and finally resulted in the deposition of $\mathrm{mp}-\mathrm{TiO}_{2}$ nanoparticles (film thickness $\approx 200 \mathrm{~nm}$, average particle size $\approx 20 \mathrm{~nm}$ ). In an inert glove box, these mp- $\mathrm{TiO}_{2}$ films were then treated with $\mathrm{PbI}_{2}$ by spin-coating at $6500 \mathrm{rpm}$ for $5 \mathrm{~s}$ from a $1.1 \mathrm{M}$ solution of $\mathrm{PbI}_{2}$ (L0279 for perovskite precursor, Tokyo Chemical Industry Co., Ltd. $)^{36}$ in DMF $(1.0 \mathrm{~mL})$, which was prepared in advance and kept at $70{ }^{\circ} \mathrm{C}$. The resulting yellow films were dried for $1 \mathrm{~h}$ on a hot plate at $70{ }^{\circ} \mathrm{C}$. The films were dipped for $1 \mathrm{~s}$ in 2-propanol, and then for $20 \mathrm{~s}$ in a $0.06 \mathrm{M}$ solution of MAI in 2-propanol $(20 \mathrm{~mL})$. The obtained perovskite films were then quickly rinsed with 2-propanol and dried on a hot plate at $70{ }^{\circ} \mathrm{C}$ for $30 \mathrm{~min}$. The hole-transporting layer was deposited on the perovskite layer by spin-coating at $4000 \mathrm{rpm}$ for $30 \mathrm{~s}$ from a $0.058 \mathrm{M}$ solution of spiro-OMeTAD (Merck) in $\mathrm{CB}(1.5 \mathrm{~mL})$ containing 4-tert-butylpyridine (43 $\mu \mathrm{L}$, 
$0.19 \mathrm{M}$, Sigma-Aldrich) and lithium bis(trifluoromethylsulphonyl)imide (13.5 mg, $0.031 \mathrm{M}$, Wako Pure Chemical Industries Ltd.) as well as tris(2-(1H-pyrazol-1-yl)-4-tert-butylpyridine)cobalt(III) $\left(12.6 \mathrm{mg}, 5.6 \times 10^{-3} \mathrm{M}\right)$ as dopants. The resulting films were dried on a hot plate at $70{ }^{\circ} \mathrm{C}$ for $30 \mathrm{~min}$.

Finally, $80 \mathrm{~nm}$ of gold was thermally evaporated on top of the active layer under high vacuum $\left(2.5 \times 10^{-4} \mathrm{~Pa}\right)$. The final layered structure of these perovskite solar cells is $\mathrm{FTO} / \mathrm{d}-\mathrm{TiO}_{2} / \mathrm{MAPbI}_{3} / \mathrm{HTM} / \mathrm{Au}$ and $\mathrm{FTO} / \mathrm{d}-\mathrm{TiO}_{2} / \mathrm{mp}-\mathrm{TiO}_{2} / \mathrm{MAPbI}_{3} / \mathrm{HTM} / \mathrm{Au}$. At least 10 devices were fabricated to ensure the reproducibility of the $J-V$ characteristics.

Measurements: The ionization potential of the polymers was measured with a photoelectron yield spectrometer (PYS, Riken Keiki, AC-3). The samples were fabricated by spin-coating from stock solution onto a washed ITO substrate. The threshold energy for the photoelectron emission was estimated on the basis of the cubic root of the photoelectron yield plotted against the incident photon energy.

Square wave voltammetry of the materials employed in this research were performed using a potentiostat/galvanostat (Princeton Applied Research, 273A) in an Ar-bubbled acetonitrile/o-DCB or $\mathrm{CF}$ solutions containing $0.1 \mathrm{M}$ of tetrabutylammonium perchlorate as a supporting electrolyte with an $\mathrm{Ag} / \mathrm{Ag}^{+}$wire as a reference electrode and a Pt wire as a counter electrode. The scan rate was set to be in the range of $20-50 \mathrm{mV} \mathrm{s}^{-1}$.

$J-V$ characteristics were measured with a direct current (DC) voltage and current source/monitor (Keithley, 2611B) in the dark and under the illumination with AM 1.5G simulated solar light with $100 \mathrm{~mW} \mathrm{~cm}^{-2}$. The light intensity was corrected with a calibrated silicon photodiode reference cell (Bunkoh-Keiki, BS-520). Temperature dependence of the $J-V$ characteristics was measured with a direct-current (DC) voltage and current source/monitor (Advantest, R6243) in a vacuum prober system (ALS Technology, VPS3-50) 
under the illumination from a $100 \mathrm{~W}$ Xe lamp (Asahi Spectra, LAX-C100) equipped with a uniform illumination lens unit (Asahi Spectra, RLQL80-0.5). The temperature was controlled by the cryocooler (Twinbird Corp., SC-UF01) and monitored the temperature controller (Panasonic, KT2). The EQE spectra were measured with a spectral response measurement system (Bunko-Keiki Co., ECT-250D). The power of the incident monochromatic light was kept under $0.05 \mathrm{~mW} \mathrm{~cm}^{-2}$, which was measured with a calibrated silicon reference cell (Bunkoh-Keiki, BS-520BK). All devices were measured in a vacuum with a metal mask to give an active area of $0.09 \mathrm{~cm}^{2}$.

\section{Supporting information}

Estimation of HOMO and LUMO levels, hysteresis of perovskite solar cells, temperature dependence of $q V_{\mathrm{OC}}$ for polymer solar cells, saturation current $\left(J_{0}\right)$, simulation of voltage loss in polymer solar cells, and fitting parameters on the simulation of voltage loss. This material is available free of charge via the Internet at http://pubs.acs.org.

\section{Acknowledgments}

This work was partly supported by the Japan Science and Technology Agency (JST) PRESTO program (Photoenergy and Conversion Systems and Materials for the Next-Generation Solar Cells) and was partly based on the results obtained from a project commissioned by the New Energy and Industrial Technology Development Organization (NEDO).

\section{REFERENCES}

(1) An, Q.; Zhang, F.; Zhang, J.; Tang, W.; Deng, Z.; Hu, B. Versatile Ternary Organic Solar Cells: A Critical Review. Energy Environ. Sci. 2016, 9, 281-322. 
(2) Yin, W.-J.; Yang, J.-H.; Kang, J.; Yan, Y.; Wei, S.-H. Halide Perovskite Materials for Solar Cells: A Theoretical Review. J. Mater. Chem. A 2015, 3, 8926-8942.

(3) Zhao, J.; Li, Y.; Yang, G.; Jiang, K.; Lin, H.; Ade, H.; Ma, W.; Yan, H. Efficient Organic Solar Cells Processed from Hydrocarbon Solvents. Nat. Energy 2016, 1, 15027-15033.

(4) Zhao, W.; Qian, D.; Zhang, S.; Li, S.; Inganäs, O.; Gao, F.; Hou, J. Fullerene-Free Polymer Solar Cells with over 11\% Efficiency and Excellent Thermal Stability. Adv. Mater. 2016, 28, 4734-4739.

(5) Vohra, V.; Kawashima, K.; Kakara, T.; Koganezawa, T.; Osaka, I.; Takimiya, K.; Murata, H. Efficient Inverted Polymer Solar Cells Employing Favourable Molecular Orientation. Nat. Photonics 2015, 9, 403-408.

(6) Konstantakou, M.; Stergiopoulos, T. A Critical Review on Tin Halide Perovskite Solar Cells. J. Mater. Chem. A, DOI: 10.1039/c7ta00929a.

(7) Ziffer, M. E.; Mohammed, J. C.; Ginger, D. S. Electroabsorption Spectroscopy Measurements of the Exciton Binding Energy, Electron-Hole Reduced Effective Mass, and Band Gap in the Perovskite $\mathrm{CH}_{3} \mathrm{NH}_{3} \mathrm{PbI}_{3}$. ACS Photonics 2016, 3, 1060-1068.

(8) Yang, Y.; Ostrowski, D. P.; France, R. M.; Zhu, K.; van de Lagemaat, J.; Luther, J. M.; Beard, M. C. Observation of a Hot-Phonon Bottleneck in Lead-Iodide Perovskites. Nat. Photonics 2016, 10, 53-59.

(9) Shi, D.; Adinolfi, V.; Comin, R.; Yuan, M.; Alarousu, E.; Buin, A.; Chen, Y.; Hoogland, S.; Rothenberger, A.; Katsiev, K.; Losovyj, Y.; Zhang, X.; Dowben, P. A.; Mohammed, O. F.; Sargent, E. H.; Bakr, O. M. Low Trap-State Density and Long Carrier Diffusion in Organolead Trihalide Perovskite Single Crystals. Science 2015, 347, 519-522.

(10) Dong, Q.; Fang, Y.; Shao, Y.; Mulligan, P.; Qiu, J.; Cao, L.; Huang J. Electron-Hole Diffusion Lengths $>175 \mu \mathrm{m}$ in Solution-Grown $\mathrm{CH}_{3} \mathrm{NH}_{3} \mathrm{PbI}_{3}$ Single Crystals. Science 2015, $347,967-970$. 
(11) Kojima, A.; Teshima, K.; Shirai, Y.; Miyasaka, T. Organometal Halide Perovskites as Visible-Light Sensitizers for Photovoltaic Cells. J. Am. Chem. Soc. 2009, 131, 6050-6051.

(12) Park, N.-G.; Grätzel, M.; Miyasaka, T.; Zhu, K.; Emery, K. Towards Stable and Commercially Available Perovskite Solar Cells. Nat. Energy 2016, 1, 16152-16159.

(13) Jeon, N. J.; Noh, J. H.; Kim, Y. C.; Yang, W. S.; Ryu, S.; Seok, S. I. Solvent Engineering for High-Performance Inorganic-Organic Hybrid Perovskite Solar Cells. Nat. Mater. 2014, 13, 897-903.

(14) Xiao, M.; Huang, F.; Huang, W.; Dkhissi, Y.; Zhu, Y.; Etheridge, J. Gray-Weale, A. Bach, U.; Cheng, Y.-B. Spiccia, L. A Fast Deposition-Crystallization Procedure for Highly Efficient Lead Iodide Perovskite Thin-Film Solar Cells. Angew. Chem. Int. Ed. 2014, 53, 9898-9903.

(15) Shockley, W.; Queisser, H. J. Detailed Balance Limit of Efficiency of p-n Junction Solar Cells. J. Appl. Phys. 1961, 32, 510-519.

(16) Li, W.; Hendriks, K. H.; Furlan, A.; Wienk, M. M.; Janssen, R. A. J. High Quantum Efficiencies in Polymer Solar Cells at Energy Losses below 0.6 eV. J. Am. Chem. Soc. 2015, $137,2231-2234$.

(17) Ran, N. A.; Love, J. A.; Takacs, C. J.; Sadhanala, A.; Beavers, J. K.; Collins, S. D.; Huang, Y.; Wang, M.; Friend, R. H.; Bazan, G. C.; Nguyen, T.-Q. Harvesting the Full Potential of Photons with Organic Solar Cells. Adv. Mater. 2016, 28, 1482-1488.

(18) Nayak, P. K.; Cahen, D. Updated Assessment of Possibilities and Limits for Solar Cells. Adv. Mater. 2014, 26, 1622-1628.

(19) Kawashima, K.; Tamai, Y.; Ohkita, H.; Osaka, I.; Takimiya, K. High-Efficiency Polymer Solar Cells with Small Photon Energy Loss. Nat. Commun. 2015, 6, 10085-10093.

(20) Snaith, H. J. Perovskites: The Emergence of a New Era for Low-Cost, High-Efficiency Solar Cells. J. Phys. Chem. Lett. 2013, 4, 3623-3630. 
(21) Tvingstedt, K.; Malinkiewicz, O.; Baumann, A.; Deibel, C.; Snaith, H. J.; Dyakonov, V.; Bolink, H. J. Radiative Efficiency of Lead Iodide Based Perovskite Solar Cells. Sci. Rep. 2014, 4, 6071-6077.

(22) Yao, J.; Kirchartz, T.; Vezie, M. S.; Faist, M. A.; Gong, W.; He, Z.; Wu, H.; Troughton, J.; Watson, T.; Bryant, D.; Nelson, J. Quantifying Losses in Open-Circuit Voltage in Solution-Processable Solar Cells. Phys. Rev. Appl. 2015, 4, 014020-014029.

(23) Tress, W.; Marinova, N.; Inganäs, O.; Nazeeruddin, M. K.; Zakeeruddin, S. M.; Gräetzel, M. Predicting the Open-Circuit Voltage of $\mathrm{CH}_{3} \mathrm{NH}_{3} \mathrm{PbI}_{3}$ Perovskite Solar Cells Using Electroluminescence and Photovoltaic Quantum Efficiency Spectra: The Role of Radiative and Non-Radiative Recombination. Adv. Energy Mater. 2015, 5, $1400812-1400817$.

(24) Gruber, M.; Wagner, J.; Klein, K.; Hörmann, U.; Opitz, A.; Stutzmann M.; Brütting, W. Thermodynamic Efficiency Limit of Molecular Donor-Acceptor Solar Cells and Its Application to Diindenoperylene $/ \mathrm{C}_{60}$-Based Planar Heterojunction Devices. Adv. Energy Mater. 2012, 2, 1100-1108.

(25) Leong, W. L.; Ooi, Z.-E.; Sabba, D.; Yi, C.; Zakeeruddin, S. M.; Graetzel, M.; Gordon, J. M.; Katz, E. A.; Mathews, N. Identifying Fundamental Limitations in Halide Perovskite Solar Cells. Adv. Mater. 2016, 28, 2439-2445.

(26) Todorov, T. K.; Gunawan, O.; Gokmen, T.; Mitzi, D. B. Solution-Processed $\mathrm{Cu}(\mathrm{In}, \mathrm{Ga})(\mathrm{S}, \mathrm{Se})_{2}$ Absorber Yielding a 15.2\% Efficient Solar Cell. Prog. Photovoltaics: Res. Appl. 2013, 21, 82-87.

(27) Yusoff, A. R. b. M.; Nazeeruddin, M. K. Organohalide Lead Perovskites for Photovoltaic Applications. J. Phys. Chem. Lett. 2016, 7, 851-866.

(28) Yamada, Y.; Nakamura, T.; Endo, M.; Wakamiya, A.; Kanemitsu, Y. Near-Band-Edge Optical Responses of Solution-Processed Organic-Inorganic Hybrid Perovskite $\mathrm{CH}_{3} \mathrm{NH}_{3} \mathrm{PbI}_{3}$ 
on Mesoporous $\mathrm{TiO}_{2}$ Electrodes. Appl. Phys. Express 2014, 7, $032302-032305$.

(29) Clarke, T. M.; Durrant, J. R. Charge Photogeneration in Organic Solar Cells. Chem. Rev. 2010, $110,6736-6767$.

(30) Thompson, B. C.; Fréchet, J. M. Polymer-Fullerene Composite Solar Cells. Angew. Chem. Int. Ed. 2008, 47, 58-77.

(31) Dennler, G.; Scharber, M. C.; Brabec, C. J. Polymer-Fullerene Bulk-Heterojunction Solar Cells. Adv. Mater. 2009, 21, 1323-1338.

(32) Kippelen, B.; Brédas, J.-L. Organic photovoltaics. Energy Environ. Sci. 2009, 2, $251-261$.

(33) Pommerehne, J.; Vestweber, H.; Guss, W.; Mahrt, R. F.; Bässler, H.; Porsch, M.; Daub, J. Efficient Two Layer LEDs on a Polymer Blend Basis. Adv. Mater. 1995, 7, 551-554.

(34) Kim, H. D.; Ohkita, H.; Benten, H.; Ito, S. Photovoltaic Performance of Perovskite Solar Cells with Different Grain Sizes. Adv. Mater. 2016, 28, 917-922.

(35) Burschka1, J.; Pellet, N.; Moon, S.-J.; Humphry-Baker, R.; Gao, P.; Nazeeruddin, M. K.; Grätzel, M. Sequential Deposition As a Route to High-Performance Perovskite-Sensitized Solar Cells. Nature 2013, 499, 316-319.

(36) Wakamiya, A.; Endo, M.; Sasamori, T.; Tokitoh, N.; Ogomi, Y.; Hayase, S.; Murata, Y. Reproducible Fabrication of Efficient Perovskite-based Solar Cells: X-ray Crystallographic Studies on the Formation of $\mathrm{CH}_{3} \mathrm{NH}_{3} \mathrm{PbI}_{3}$ Layers. Chem. Lett. 2014, 43, 711-713.

(37) Yamamoto, S.; Orimo, A.; Ohkita, H.; Benten, H.; Ito, S. Molecular Understanding of the Open-Circuit Voltage of Polymer:Fullerene Solar Cells. Adv. Energy Mater. 2012, 2, $229-237$.

(38) Lindqvist, C.; Bergqvist, J.; Feng, C.-C.; Gustafsson, S.; Bäcke, O.; Treat, N. D.; Bounioux, C.; Henriksson, P.; Kroon, R.; Wang, E.; Sanz-Velasco, A.; Kristiansen, P. M.; Stingelin, N.; Olsson, E.; Inganäs, O.; Andersson, M. R.; Müller, C. Fullerene Nucleating 
Agents: A Route Towards Thermally Stable Photovoltaic Blends. Adv. Energy Mater. 2014, 4, $1301437-1301446$.

(39) Wakim, S.; Beaupré, S.; Blouin, N.; Aich, B.-R.; Rodman, S.; Gaudiana, R.; Tao, Y.; Leclerc, M. Highly Efficient Organic Solar Cells Based on a Poly(2,7-carbazole) Derivative. $J$. Mater. Chem. 2009, 19, 5351-5358.

(40) Benten, H.; Mori, D.; Ohkita, H.; Ito, S. Recent Research Progress of Polymer Donor/Polymer Acceptor Blend Solar Cells. J. Mater. Chem. A 2016, 4, 5340-5365.

(41) Mori, D.; Benten, H.; Okada, I.; Ohkita, H.; Ito, S. Low-Bandgap Donor/Acceptor Polymer Blend Solar Cells with Efficiency Exceeding 4\%. Adv. Energy Mater. 2014, 4, 1301006-1301011.

(42) Benten, H.; Nishida, T.; Mori, D.; Xu, H.; Ohkita, H.; Ito, S. High-Performance Ternary Blend All-Polymer Solar Cells with Complementary Absorption Bands from Visible to Near-Infrared Wavelengths. Energy Environ. Sci. 2016, 9, 135-140.

(43) Sze, S. M. Physics of Semiconductor Devices, 2nd ed; John Wiley \& Sons: New York, 1981.

(44) Nelson, J. The Physics of Solar Cells, Imperial College Press: London, 2003.

(45) Torabi, S.; Jahani, F.; Severen, I. V.; Kanimozhi, C.; Patil, S.; Havenith, R. W. A.; Chiechi, R. C.; Lutsen, L.; Vanderzande, D. J. M.; Cleij, T. J.; Hummelen, J. C.; Koster, L. J. A. Strategy for Enhancing the Dielectric Constant of Organic Semiconductors Without Sacrificing Charge Carrier Mobility and Solubility. Adv. Funct. Mater. 2015, 25, 150-157.

(46) Yang, P.; Yuan, M.; Zeigler, D. F.; Watkins, S. E.; Lee. J. A.; Luscombe. C. K. Influence of Fluorine Substituents on the Film Dielectric Constant and Open-Circuit Voltage in Organic Photovoltaics. J. Mater. Chem. C 2014, 2, 3278-3284.

(47) Nalwa, H. S. Handbook of Low and High Dielectric Constant Materials and Their Applications. Academic Press: London, UK, 1999. 
(48) Häusermann, R.; Knapp, E.; Moos, M.; Reinke, N. A.; Flatz, T.; Ruhstaller. B. Coupled Optoelectronic Simulation of Organic Bulk-Heterojunction Solar Cells: Parameter Extraction and Sensitivity Analysis. J. Appl. Phys. 2009, 106, 104507-104515.

(49) Ziffer, M. E.; Mohammed, J. C.; Ginger, D. S. Electroabsorption Spectroscopy Measurements of the Exciton Binding Energy, Electron-Hole Reduced Effective Mass, and Band Gap in the Perovskite $\mathrm{CH}_{3} \mathrm{NH}_{3} \mathrm{PbI}_{3}$. ACS Photonics 2016, 3, 1060-1068.

(50) Phuong, L. Q.; Nakaike, Y.; Wakamiya, A.; Kanemitsu, Y. Free Excitons and Exciton-Phonon Coupling in $\mathrm{CH}_{3} \mathrm{NH}_{3} \mathrm{PbI}_{3}$ Single Crystals Revealed by Photocurrent and Photoluminescence Measurements at Low Temperatures. J. Phys. Chem. Lett. 2016, 7, $4905-4910$.

(51) Nadenau, V.; Rau, U.; Jasenek, A.; Schock, H. W. Electronic Properties of $\mathrm{CuGaSe}_{2}$-Based Heterojunction Solar Cells. Part I. Transport analysis. J. Appl. Phys. 2000, 87, 584-593.

(52) Bozyigit, D.; Lin, W. M. M.; Yazdani, N.; Yarema, O.; Wood, V. A Quantitative Model for Charge Carrier Transport, Trapping and Recombination in Nanocrystal-Based Solar Cells. Nat. Commun. 2015, 6, 6180-6189.

(53) Kim, H. D.; Miyamoto, Y.; Kubota, H.; Yamanari, T.; Ohkita, H. Open-Circuit Voltage Loss in $\mathrm{CH}_{3} \mathrm{NH}_{3} \mathrm{SnI}_{3}$ Perovskite Solar Cells. Chem. Lett. 2017, 46, 253-256.

(54) Zheng, X.; Chen, B.; Yang, M.; Wu, C.; Orler, B.; Moore, R. B.; Zhu, K.; Priya, S. The Controlling Mechanism for Potential Loss in $\mathrm{CH}_{3} \mathrm{NH}_{3} \mathrm{PbBr}_{3}$ Hybrid Solar Cells. ACS Energy Lett. 2016, 1, 424-430.

(55) Vandewal, K.; Tvingstedt, K.; Gadisa, A.; Inganäs, O.; Manca, J. V. Relating the Open-Circuit Voltage to Interface Molecular Properties of Donor:Acceptor Bulk Heterojunction Solar Cells. Phys. Rev. B 2010, 81, 125204-125211.

(56) Hörmann, U.; Kraus, J.; Gruber, M.; Schuhmair, C.; Linderl, T.; Grob, S.; Kapfinger, S.; 
Klein, K.; Stutzman, M.; Krenner, H. J.; Brütting, W. Quantification of Energy Losses in Organic Solar Cells from Temperature-Dependent Device Characteristics. Phys. Rev. B 2013, $88,235307-235319$.

(57) Liu, Y.; Zojer, K.; Lassen, B.; Kjelstrup-Hansen, J.; Rubahn, H.-G.; Madsen, M. Role of the Charge-Transfer State in Reduced Langevin Recombination in Organic Solar Cells: A Theoretical Study. J. Phys. Chem. C 2015, 119, 26588-26597.

(58) Elumalai, N. K.; Uddin, A. Open Circuit Voltage of Organic Solar Cells: An In-Depth Review. Energy Environ. Sci. 2016, 9, 391-410.

(59) Giebink, N. C.; Wiederrecht, G. P.; Wasielewski, M. R.; Forrest, S. R. Thermodynamic Efficiency Limit of Excitonic Solar Cells. Phy. Rev. B 2011, 83, 195326-195331.

(60) Koster, L. J. A.; Shaheen, S. E.; Hummelen, J. C. Pathways to a New Efficiency Regime for Organic Solar Cells. Adv. Energy Mater. 2012, 2, 1246-1253.

(61) Janssen, R. A. J.; Nelson, J. Factors Limiting Device Efficiency in Organic Photovoltaics. Adv. Mater. 2013, 25, 1847-1858.

(62) Vandewal, K.; Gadisa, A.; Oosterbaan, W. D.; Bertho, S.; Banishoeib, F.; Severen, I. V.; Lutsen, L.; Cleij, T. J.; Vanderzande, D.; Manca, J. V. The Relation Between Open-Circuit Voltage and the Onset of Photocurrent Generation by Charge-Transfer Absorption in Polymer : Fullerene Bulk Heterojunction Solar Cells. Adv. Funct. Mater. 2008, 18, 2064-2070.

(63) Baran, D.; Kirchartz, T.; Wheeler, S.; Dimitrov, S.; Abdelsamie, M.; Gorman, J.; Ashraf, R. S.; Holliday, S.; Wadsworth, A.; Gasparini, N.; Kaienburg, P.; Yan, H.; Amassian, A.; Brabec, C. J.; Durrant, J. R.; McCulloch, I. Reduced Voltage Losses Yield 10\% Efficient Fullerene Free Organic Solar Cells with $>1$ V Open Circuit Voltages. Energy Environ. Sci. 2016, 9, 3783-3793.

(64) Tvingstedt, K.; Deibel, C. Temperature Dependence of Ideality Factors in Organic Solar 
Cells and the Relation to Radiative Efficiency. Adv. Energy Mater. 2016, 6, $1502230-1502242$.

(65) Vandewal, K.; Tvingstedt, K.; Gadisa, A.; Inganäs, O.; Manca, J. V. Relating the Open-Circuit Voltage to Interface Molecular Properties of Donor:Acceptor Bulk Heterojunction Solar Cells. Phys. Rev. B 2010, 81, 125204-125211.

(66) Burke, T. M.; Sweetnam, S.; Vandewal, K.; McGehee, M. D. Beyond Langevin Recombination: How Equilibrium Between Free Carriers and Charge Transfer States Determines the Open-Circuit Voltage of Organic Solar Cells. Adv. Energy Mater. 2015, 5, $1500123-1500134$.

(67) Kirchartz, T.; Pieters, B. E.; Kirkpatrick, J.; Rau, U.; Nelson, J. Recombination via Tail States in Polythiophene:Fullerene Solar Cells. Phys. Rev. B 2011, 83, 115209-115221.

(68) Kirchartz, T.; Nelson, J. Meaning of Reaction Orders in Polymer:Fullerene Solar Cells. Phys. Rev. B 2012, 86, 165201-165212.

(69) Stranks, S. D.; Snaith, H. J. Metal-Halide Perovskites for Photovoltaic and Light-Emitting Devices. Nat. Nanotechnol. 2015, 10, 391-402.

(70) Kronemeijer, A. J.; Pecunia, V.; Venkateshvaran, D.; Nikolka, M.; Sadhanala, A.; Moriarty, J.; Szumilo, M.; Sirringhaus, H. Two-Dimensional Carrier Distribution in Top-Gate Polymer Field-Effect Transistors: Correlation between Width of Density of Localized States and Urbach Energy. Adv. Mater. 2014, 26, 728-733.

(71) Venkateshvaran, D.; Nikolka, M.; Sadhanala, A.; Lemaur, V.; Zelazny, M.; Kepa, M.; Hurhangee, M.; Kronemeijer, A. J.; Pecunia, V.; Nasrallah, I.; Romanov, I.; Broch, K.; McCulloch, I.; Emin, D.; Olivier, Y.; Cornil, J.; Beljonne, D.; Sirringhaus, H. Approaching Disorder-Free Transport in High-Mobility Conjugated Polymers. Nature 2014, 515, 384-388. (72) Leijtens, T.; Eperon, G. E.; Barker, A. J.; Grancini, G.; Zhang, W.; Ball, J. M.; Kandada, A. R. S.; Snaith, H. J.; Petrozza, A. Carrier Trapping and Recombination: The Role of Defect 
Physics in Enhancing The Open Circuit Voltage of Metal Halide Perovskite Solar Cells. Energy Environ. Sci. 2016, 9, 3472-3481.

(73) Shi, D.; Adinolfi, V.; Comin, R.; Yuan, M.; Alarousu, E.; Buin, A.; Chen, Y.; Hoogland, S.; Rothenberger, A.; Katsiev, K.; Losovyj, Y.; Zhang, X.; Dowben, P. A.; Mohammed, O. F.; Sargent, E. H.; Bakr, O. M. Low Trap-State Density and Long Carrier Diffusion in Organolead Trihalide Perovskite Single Crystals. Science 2015, 347, 519-521.

(74) Nie, W.; Tsai, H.; Asadpour, R.; Blancon, J.-C.; Neukirch, A. J.; Gupta, G.; Crochet, J. J.; Chhowalla, M.; Tretiak, S.; Alam, M. A.; Wang, H.-L.; Mohite, A. D. High-Efficiency Solution-Processed Perovskite Solar Cells with Millimeter-Scale Grains. Science 2015, 347, $522-525$.

(75) Yen, H.-J.; Liang, P.-W.; Chueh, C.-C.; Yang, Z.; Jen, A. K.-Y.; Wang, H.-L. Large Grained Perovskite Solar Cells Derived from Single-Crystal Perovskite Powders with Enhanced Ambient Stability. ACS Appl. Mater. Interfaces 2016, 8, 14513-14520.

(76) Yablonovitch, E. Lead Halides Join the Top Optoelectronic League. Science 2016, 351, 1401.

(77) Pazos-Outón, L. M.; Szumilo, M.; Lamboll, R.; Richter, J. M.; Crespo-Quesada, M.; Abdi-Jalebi, M.; Beeson, H. J.; Vrućinić, M.; Alsari, M.; Snaith, H. J.; Ehrler, B.; Friend, R. H.; Deschler, F. Photon Recycling in Lead Iodide Perovskite Solar Cells. Science 2016, 351, $1430-1433$.

(78) Yamada, Y.; Yamada, T.; Phuong, L. Q.; Maruyama, N.; Nishimura, H.; Wakamiya, A.; Murata, Y.; Kanemitsu, Y. Dynamic Optical Properties of $\mathrm{CH}_{3} \mathrm{NH}_{3} \mathrm{PbI}_{3}$ Single Crystals As Revealed by One- and Two-Photon Excited Photoluminescence Measurements. J. Am. Chem. Soc. 2015, 137, 10456-10459. 
Figures and Figure Captions

a)

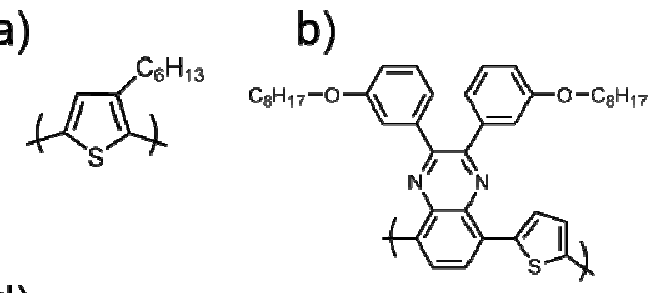

d)

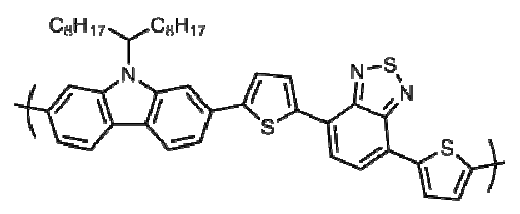

e)

f)

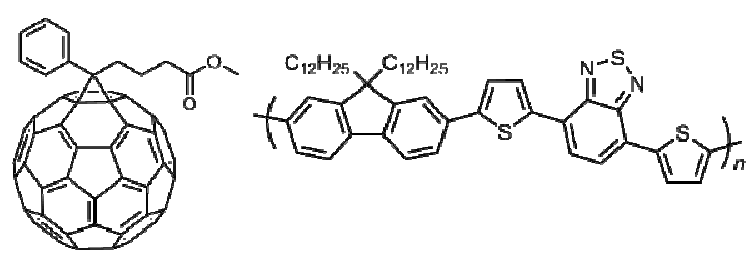

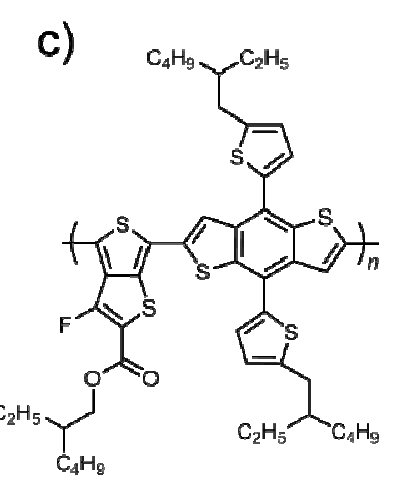

g)

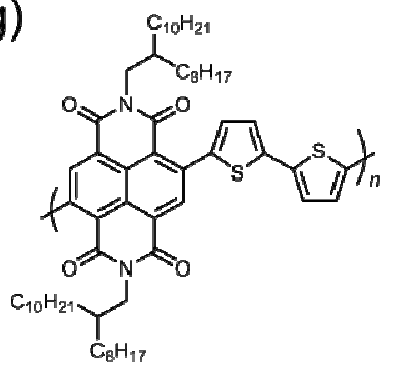

Figure 1. Chemical structures of donor polymers (a-d) and acceptor polymers $(\mathrm{e}-\mathrm{g})$ employed in this study: a) P3HT, b) PTQ1, c) PBDTTT-EF-T, d) PCDTBT, e) PCBM, f) PF12TBT, and g) N2200. 

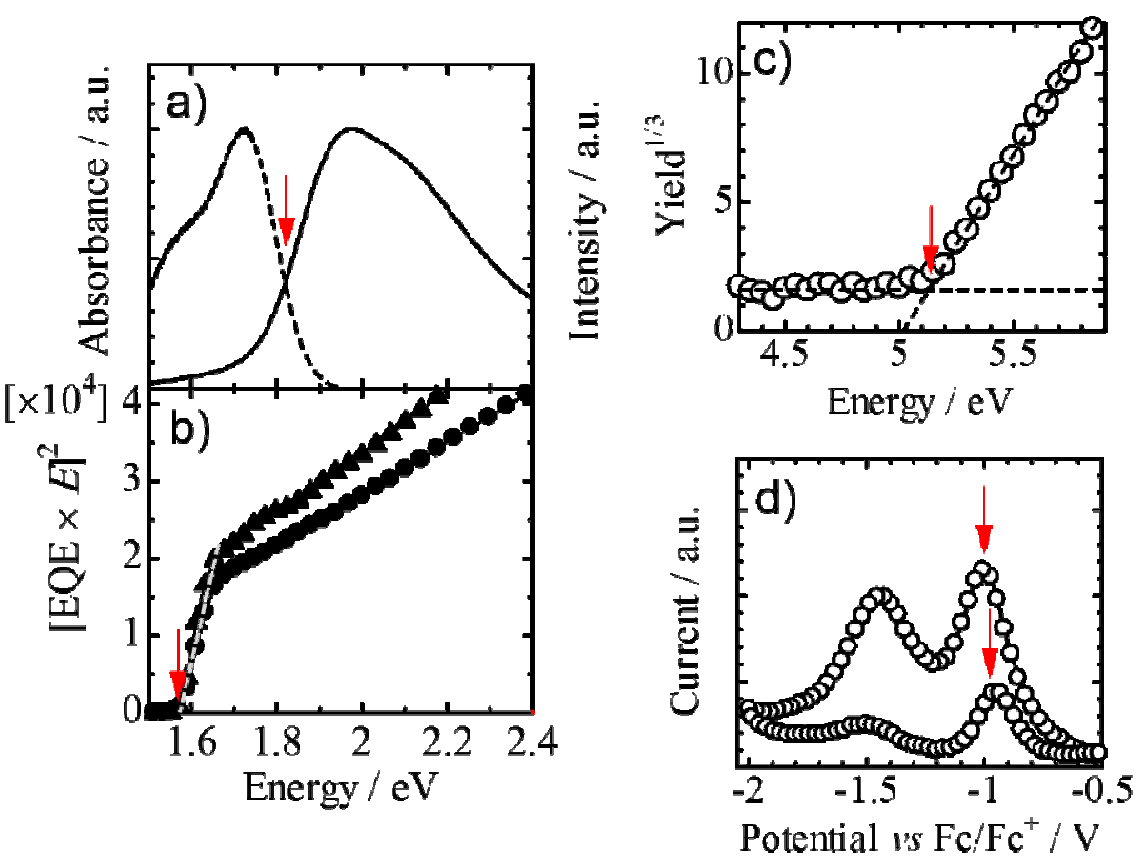

Figure 2. a) Absorption (solid line) and photoluminescence spectra (broken line) of PTQ1. b) $(\mathrm{EQE} \times E)^{2}$ plotted against the photon energy $E:$ mp- $\mathrm{TiO}_{2}$ based $\mathrm{MAPbI}_{3}$ solar cells (close circles) and $\mathrm{d}-\mathrm{TiO}_{2}$ based $\mathrm{MAPbI}_{3}$ solar cells (close triangles). The broken line shows the $x$-intercept. c) Photoelectron yield spectroscopy of a PBDTTT-EF-T film. The cut-off energy was estimated by the threshold of the cubic root of the photoelectron yield. d) Square wave voltammetry of an N2200 film in acetonitrile/o-dichlorobenzene solutions containing $0.1 \mathrm{M}$ of tetrabutylammonium perchlorate. The scan rate is set to be in the range of $20-50 \mathrm{mV} \mathrm{s}^{-1}$. 


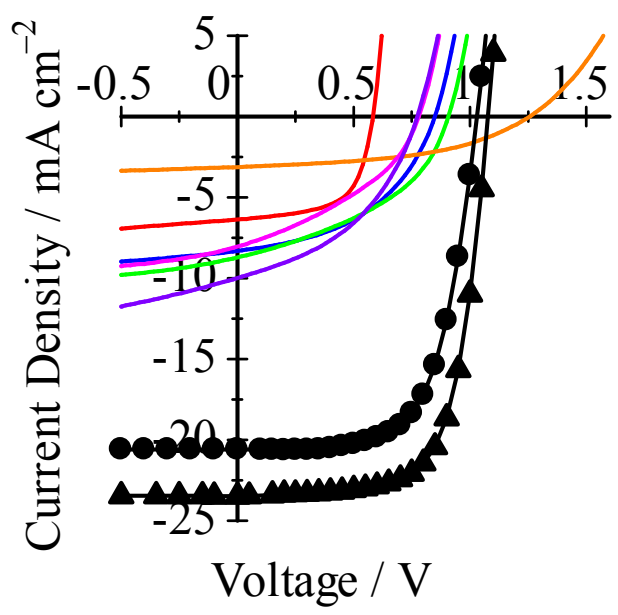

Figure 3. $J-V$ characteristics of polymer solar cells (solid lines) and perovskite solar cells (symbols) under AM 1.5G simulated solar illumination with $100 \mathrm{~mW} \mathrm{~cm}{ }^{-2}$ : P3HT/PCBM (red), PTQ1/PCBM (blue), PCDTBT/PCBM (green), P3HT/PF12TBT (orange), PTQ1/N2200 (magenta), PBDTTT-EF-T/N2200 (purple), mp-TiO ${ }_{2}$ based $\mathrm{MAPbI}_{3}$ solar cells (close circles), and $\mathrm{d}-\mathrm{TiO}_{2}$ based $\mathrm{MAPbI}_{3}$ solar cells (close triangles). All the devices were measured in a nitrogen atmosphere with a metal mask to give an active area of $0.09 \mathrm{~cm}^{2} . J-V$ characteristics of perovskite solar cells were measured from 1.2 to $-0.50 \mathrm{~V}$ (reverse scan) with a delay time of $1 \mathrm{~s}$. 


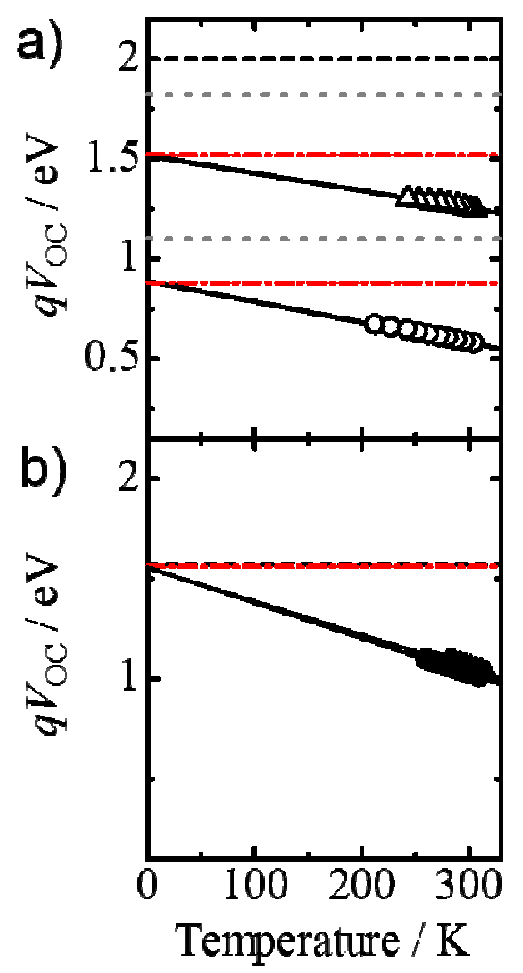

Figure 4. Temperature dependence of $q V_{\mathrm{OC}}$ for a) polymer solar cells and b) perovskite solar cells: P3HT/PCBM (open circles), P3HT/PF12TBT (open triangles), mp- $\mathrm{TiO}_{2}$ based $\mathrm{MAPbI}_{3}$ solar cells (close circles), and $\mathrm{d}-\mathrm{TiO}_{2}$ based $\mathrm{MAPbI}_{3}$ solar cells (close triangles). The solid lines are extracted by a fit to experimental data with Equation (1). The correlation coefficients $(r)$ between the data and the fitting line are more than 0.99: P3HT/PCBM $(r=$ 0.9994), P3HT/PF12TBT ( $r=0.9926)$, mp- $\mathrm{TiO}_{2}$ based $\mathrm{MAPbI}_{3}$ solar cells $(r=0.9990)$, and d- $\mathrm{TiO}_{2}$ based $\mathrm{MAPbI}_{3}$ solar cells $(r=0.9910)$. The broken and dotted lines represent bandgap energy $\left(E_{\mathrm{g}}\right)$ and $\mathrm{CT}$ state energy $\left(E_{\mathrm{DA}}\right)$, respectively. The dashed-dotted lines indicate the effective bandgap energy $\left(E_{\mathrm{g}}{ }^{\text {eff }}\right)$. 

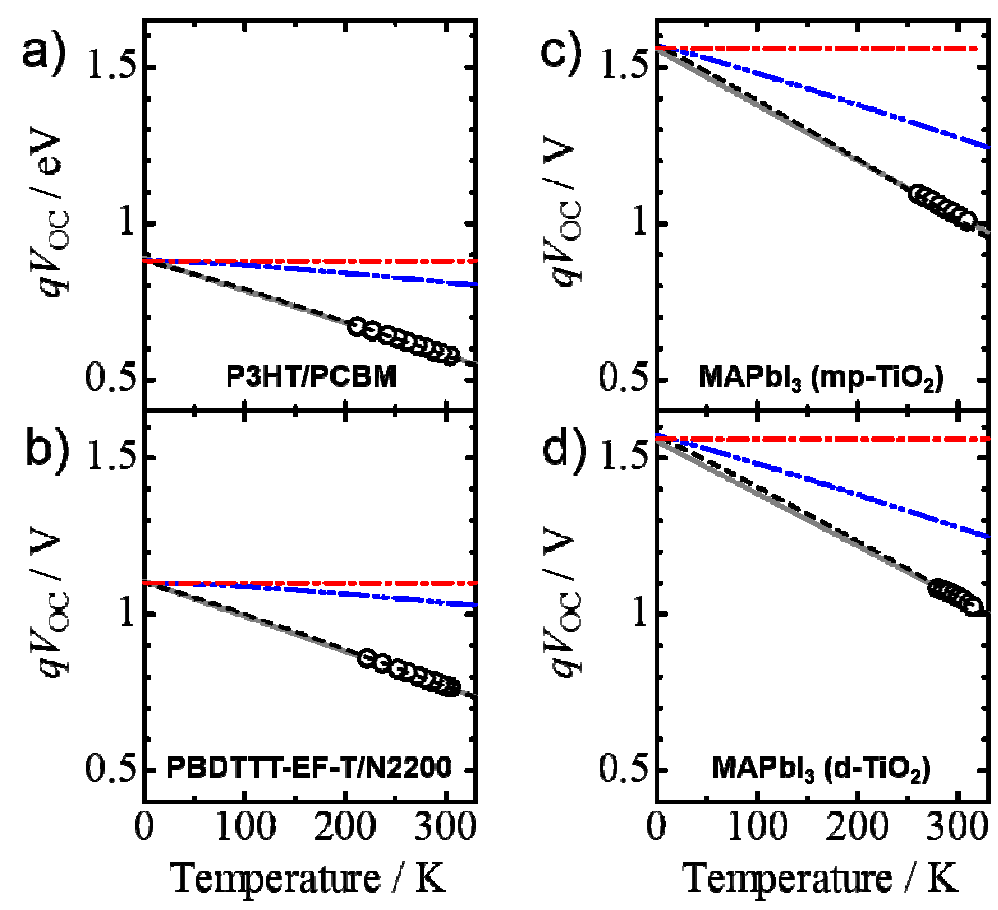

Figure 5. Temperature dependence of $q V_{\mathrm{OC}}$ split into two types of loss processes based on the modified SQ theory in polymer solar cells $(a-b)$ and perovskite solar cells $(c-d)$. The dashed-dotted lines represent the effective bandgap energy $\left(E_{\mathrm{g}}{ }^{\text {eff }}\right)$. The black broken lines are the calculated values on the basis of Equation (6) taking into account $J_{0}$ that both radiative and non-radiative recombination contribute to device current. This is good agreement with the grey solid lines, which were extracted by a fit to experimental data with Equation (1). The correlation coefficients $(r)$ between the data and the fitting line are more than 0.99 : P3HT/PCBM $(r=0.9994)$, PBDTTT-EF-T/N2200 $(r=0.9999)$, mp-TiO 2 based $\mathrm{MAPbI}_{3}$ solar cells $(r=0.9990)$, and $\mathrm{d}-\mathrm{TiO}_{2}$ based $\mathrm{MAPbI}_{3}$ solar cells $(r=0.9910)$. The blue dashed-two-dotted lines represent thermodynamically inevitable loss in $V_{\mathrm{OC}}$ as a function of temperature. In this simulation, $\beta=J_{0, \text { non }} / J_{0 \text {,rad }}$ was employed as a fitting parameter, which is independent of temperature. Each experimental $J_{\mathrm{SC}}$ measured was used to fit the temperature dependent $V_{\mathrm{OC}} . \quad \eta_{\mathrm{A}}{ }^{\mathrm{CT}}$ was fixed at $1.0 \times 10^{-4}$ for all the polymer solar cells. 


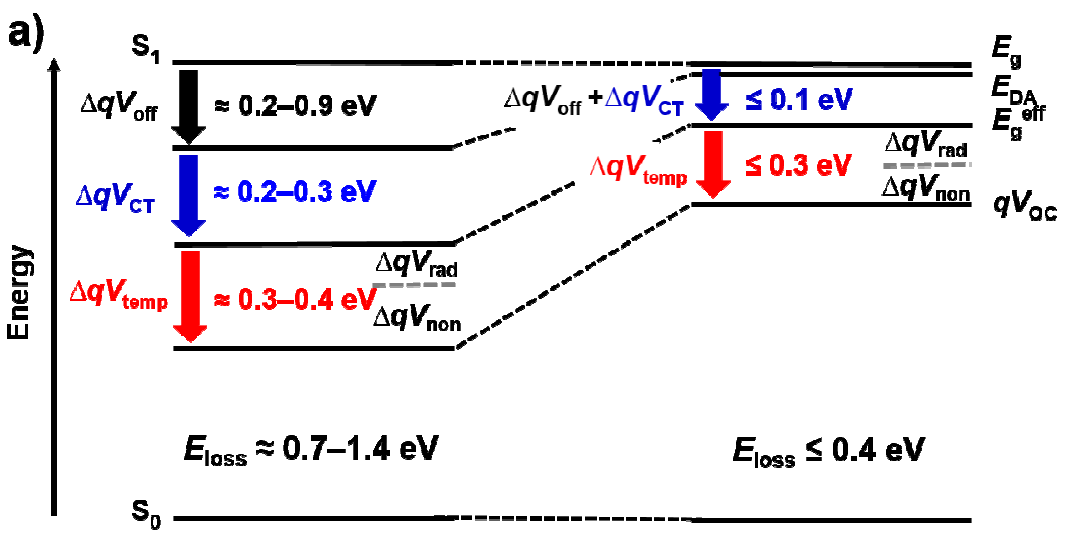

b)

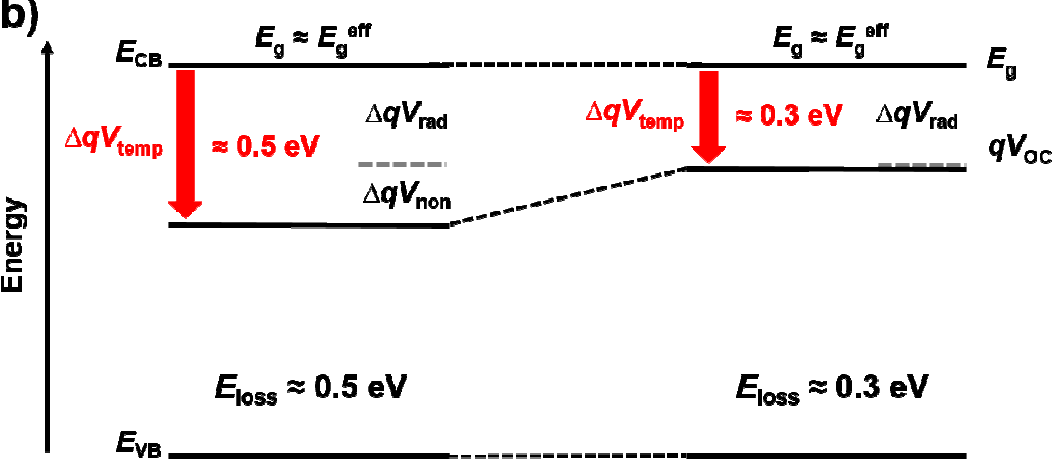

Figure 6. Energy diagrams for a) polymer solar cells and b) perovskite solar cells. The black and grey broken lines represent an extension of each energy level and the Shockley-Queisser (SQ) limit, respectively. The right-hand side of figures shows the upper limit of $V_{\mathrm{OC}}$ attainable for polymer solar cells and perovskite solar cells, respectively. 
Table 1. The bandgap energy $\left(E_{\mathrm{g}}\right)$, the energy gap between HOMO of donor and LUMO of acceptor $\left(E_{\mathrm{DA}}\right)$, the effective bandgap energy $\left(E_{\mathrm{g}}{ }^{\text {eff }}\right)$, and the energy loss of each loss process in polymer solar cells and perovskite solar cells.

\begin{tabular}{|c|c|c|c|c|c|c|c|c|}
\hline Devices & $\begin{array}{c}E_{\mathrm{g}} \\
(\mathrm{eV})\end{array}$ & $\begin{array}{c}q V_{\mathrm{OC}} \\
(\mathrm{eV})\end{array}$ & $\begin{array}{l}E_{\text {loss }} \\
(\mathrm{eV})\end{array}$ & $\begin{array}{l}E_{\mathrm{DA}} \\
(\mathrm{eV})\end{array}$ & $\begin{array}{l}E_{\mathrm{g}}{ }^{\mathrm{eff}} \\
(\mathrm{eV})\end{array}$ & $\begin{array}{c}\Delta q V_{\text {off }} \\
(\mathrm{eV})\end{array}$ & $\begin{array}{c}\Delta q V_{\mathrm{CT}} \\
(\mathrm{eV})\end{array}$ & $\begin{array}{c}\Delta q V_{\text {temp }} \\
(\mathrm{eV})\end{array}$ \\
\hline P3HT/PCBM & 2.00 & 0.59 & 1.41 & 1.10 & 0.88 & 0.90 & 0.22 & 0.29 \\
\hline PTQ1/PCBM & 1.81 & 0.85 & 0.96 & 1.36 & 1.17 & 0.45 & 0.19 & 0.32 \\
\hline PCDTBT/PCBM & 1.90 & 0.91 & 0.99 & 1.54 & 1.31 & 0.36 & 0.23 & 0.40 \\
\hline P3HT/PF12TBT & 2.00 & 1.26 & 0.74 & 1.82 & 1.52 & 0.18 & 0.30 & 0.26 \\
\hline PTQ1/N2200 & 1.81 & 0.78 & 1.03 & 1.38 & 1.04 & 0.43 & 0.34 & 0.26 \\
\hline PBDTTT-EF-T/N2200 & 1.67 & 0.77 & 0.90 & 1.37 & 1.10 & 0.30 & 0.27 & 0.33 \\
\hline $\mathrm{MAPbI}_{3}\left(\mathrm{mp}-\mathrm{TiO}_{2}\right)$ & 1.57 & 1.03 & 0.54 & - & 1.56 & - & - & 0.53 \\
\hline $\mathrm{MAPbI}_{3}\left(\mathrm{~d}-\mathrm{TiO}_{2}\right)$ & 1.57 & 1.06 & 0.51 & - & 1.56 & - & - & 0.50 \\
\hline
\end{tabular}




\section{TOC GRAPHICS}

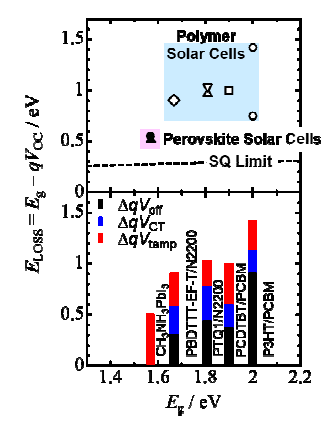

16

17

18

19

20

21

22

23

24

25

26

27

28

29

30

31

32

33

34

35

36

37

38

39

40

41

42

43

44

45

46

47

48

49

50

51

52

53

54

55

56

57

58

59

60 